\title{
PENGEMBANGAN MEDIA PEMBELAJARAN VIRTUAL LAB DALAM PRAKTIKUM LAJU REAKSI
}

\author{
${ }^{1}$ Atna Tirmizi, Rahmanpiu' ${ }^{2}$ \\ ${ }^{1,2}$ Program Studi Pendidikan Kimia FKIP, Universitas Halu Oleo, Kendari \\ Corresponding author:rahmanpiu.fkip@uho.ac.id
}

\begin{abstract}
Research has been carried out on the Development of Virtual Lab Learning Media in the Reaction Rate Practicum at SMA Negeri 02 Bombana. This study aims to describe the validity, responses of teachers and students in the developed reaction rate practicum. The research method used is R\&D (Research and Development) and the development model used is the 4D development model which stands for define, design, development and disseminate, but does not reach the disseminate stage only to development. The validity of the virtual lab development results is measured based on the results of expert validation. Teacher and student responses are measured based on teacher assessments and student responses to the developed product. The results showed that the average assessment of material experts was 2.91 (very good criteria) and the average assessment of media experts was 2.83 (very good criteria). The virtual laboratory acceptance level by students reached the very supportive criteria of $90 \%$ (limited scale trial). Meanwhile, the level of acceptance of the virtual laboratory by the teacher reaches the supporting criteria of $50 \%$ (limited scale trial). The average score of each item of student and teacher responses reached the very supportive criteria. Based on expert validation, teacher and student responses, the virtual laboratory is feasible to be used as a learning medium in the reaction rate practicum.
\end{abstract}

Keywords: Development; virtual lab; reaction rate; Research and Development; 4-D development

\section{PENDAHULUAN}

Kimia merupakan
pengetahuan yang dilandasi
dengan eksperimen, di mana
perkembangan dan aplikasinya
menjadi standar kerja eksperimen

(Pujiati dan Nurhayati, 2012). Mata pelajaran kimia di SMA memiliki tujuan memperoleh pengalaman dalam menerapkan metode ilmiah melalui percobaan dimana siswa melakukan pengujian hipotesis dengan

JPKim FKIP UHO, Vol.6, No.3, Desember 2021 | Hal. 149 
melakukan

eksperimen, pengambilan data dan interpretasi data, serta mengkomunikasikan hasil eksperimen secara lisan dan tertulis (Nuh, 2014).

Eksperimen atau kegiatan praktikum sangat penting untuk dilakukan, karena jika kegiatan praktikum dilaksanakan setidaknya akan dapat meningkatkan motivasi, pemahaman, serta keterampilan personal sosial siswa (Rahayu, dkk., 2014). Namun demikian, tidak semua sekolah dapat melaksanakan kegiatan eksperimen karena terbatasnya sarana dan prasarana. Salah satu sekolah di Sulawesi Tenggara yang hanya menyelenggarakan pembelajaran tanpa praktikum adalah SMA Negeri 02 Bombana. Berdasarkan hasil observasi dan wawancara dengan salah seorang guru kimia di SMA Negeri 02 Bombana, menyatakan bahwa pembelajaran kimia pada materi laju reaksi yang dilakukan di sekolah tersebut masih menggunakan metode ceramah dan diskusi, sehingga proses pembelajaran hanya berpedoman pada guru dan buku teks. Proses pembelajaran seperti ini sangat berpengaruh terhadap hasil belajar peserta didik karena tidak semua peserta didik dilibatkan dalam proses pembelajaran, sehingga pembelajaran yang dilakukan belum sesuai dengan tujuan.

Salah satu cara untuk mengatasi masalah tersebut yaitu dengan dilakukannya praktikum virtual lab. Hamida, dkk (2013) mengemukakan bahwa untuk melaksanakan praktikum tidak hanya melakukan eksperimen di dalam laboratorium, siswa juga dapat melakukannya pada virtual lab. Laboratorium virtual atau biasa disebut dengan istilah Virtual Lab adalah serangkaian alat, bahan, serta laboratorium berupa perangkat lunak (software) komputer, yang dioperasikan dengan komputer dan dapat mensimulasikan kegiatan di laboratorium seakan-akan pengguna berada pada laboratorium sebenarnya (Kusumaningsih, 2014). Carnevale (2003) mengemukakan bahwa pembelajaran berbasis praktikum virtual dapat memberikan keleluasaan (flexibility) terhadap waktu dan tempat dalam melakukannya dan hambatan lain seperti tidak tersedianya laboratorium di sekolah dapat diatasi dengan kegiatan praktikum virtual. Virtual lab tentu tidak dapat digunakan untuk menggantikan kegiatan praktikum di dalam laboratorium yang sebenarnya, karena kegiatan praktikum dalam virtual lab tidak dapat melatih kemampuan proses siswa yang hanya akan didapat dari kegiatan praktikum di laboratorium sebenarnya, namun virtual lab ini dapat digunakan sebagai media pembelajaran yang membantu siswa dalam memahami materi yang akan dipelajari (Nurrokhmah dan Sunarto, 2013).

Media pembelajaran adalah segala sesuatu yang dapat digunakan untuk menyalurkan pesan dan dapat merangsang pikiran, perasaan, perhatian dan 
kemauan siswa sehingga mendorong terjadinya proses belajar pada diri siswa. Media memegang peranan yang penting dalam proses pembelajaran. Keberhasilan pembelajaran sangat ditentukan oleh dua komponen utama yaitu metode mengajar dan media pembelajaran. Kerumitan bahan yang akan disampaikan kepada peserta didik dapat disederhanakan dengan bantuan media. Penggunaan media pembelajaran berbantuan komputer mempunyai pengaruh yang besar terhadap daya tarik peserta didik untuk mempelajari dan memahami materi.

Materi yang akan dipelajari haruslah sesuai dengan kompetensi dasar yang terdapat dalam Permendikbud Nomor 59 Tahun 2014. Adapun kompetensi dasar (KD) pengetahuan untuk materi laju reaksi adalah KD 3.7 yaitu Menganalisis faktor-faktor yang mempengaruhi laju reaksi dan menentukan orde reaksi berdasarkan data hasil percobaan, dan untuk keterampilannya adalah KD 4.7 yaitu Merancang, melakukan, dan menyimpulkan serta menyajikan hasil percobaan faktor-faktor yang mempengaruhi laju reaksi dan orde reaksi. Berdasarkan KD tersebut, maka perlu untuk dilakukannya percobaan atau praktikum dalam materi laju reaksi khususnya pada materi faktor-faktor yang mempengaruhi laju reaksi. Dilihat dari kendala yang menyebabkan kegiatan praktikum tidak dilakukan sehingga pembelajaran berbasis virtual lab adalah solusi yang mungkin untuk dilakukan.

Hasil penelitian sebelumnya tentang pengembangan virtual laboratory sebagai media pembelajaran berbasis komputer pada materi pembiakan virus menunjukkan bahwa dengan menggunakan media pembelajaran virtual lab berada pada kriteria sangat baik dan baik. Selain itu pada Tingkat keberterimaan virtual laboratory oleh siswa mencapai kriteria mendukung dan sangat mendukung sebesar 96\% (Felintina, 2011). Selain itu penelitian lain ditunjukkan pada materi larutan elektrolit dan nonelektrolit mengemukakan bahwa hasil dari pengembangan laboratorium virtual menunjukkan bahwa media pembelajaran laboratorium virtual yang dikembangkan layak untuk digunakan. Hal ini ditunjukkan dari hasil validasi dosen ahli diperoleh persentase rata-rata kelayakan sebesar 88,53\%. Kemudian hasil uji coba kelompok Terbatas pada 10 orang siswa diperoleh rata-rata persentase kelayakan sebesar 91\% (Khaeruman, dkk 2015).

Berdasarkan uraian diatas dapat disimpulkan bahwa penelitian media pembelajaran Virtual Lab sangat mendukung dan layak disekolah. Namun hingga saat ini disekolah SMA 02 Bombana belum ada yang melakukan penelitian ini. Maka perlu dilakukan penelitian dengan judul "Pengembangan Media Pembelajaran Virtual Lab dalam Praktikum Laju Reaksi" yang bertujuan untuk mengetahui 
tingkat kevalidan media pembelajaran virtual lab dalam praktikum laju reaksi dari hasil pengembangan yang dilakukan dan mendeskripsikan tanggapan guru dan siswa terhadap virtual lab dalam praktikum laju reaksi dari hasil pengembangan yang dilakukan.

\section{METODE PENELITIAN}

Jenis digunakan penelitian Research and Development (R\&D). $R \& D$ merupakan metode penelitian yang digunakan untuk menghasilkan suatu produk tertentu (Sugiyono, 2015). Penelitian $R \& D$ menekankan suatu produk yang dapat bermanfaat dalam berbagai bentuk sebagai perluasan, tambahan dan inovasi dari bentuk yang telah ada (Putra, 2013. Produk tersebut dapat berbentuk benda atau perangkat keras (hardware) seperti buku, modul, alat bantu pembelajaran di kelas atau di laboratorium atau perangkat lunak (software) seperti program komputer, model pembelajaran dan lain - lain (Trianto, 2010). Penelitian ini akan dikembangkan dan dihasilkan suatu produk. Media yang dikembangkan oleh peneliti yaitu menggunakan perangkat lunak PowerPoint.

\section{Teknik Pengumpulan Data}

Teknik pengumpulan data pada penelitian pendahuluan dalam penelitian ini adalah pemberian angket terhadap 2 orang guru kimia dan 10 siswa kelas XII IPA. Angket yang digunakan pada penelitian ini berupa angket dengan jawaban tertutup yaitu jawaban sangat setuju (SS), setuju (S), kurang setuju (KR), dan tidak setuju (TS) serta ditanggapi dengan memberi saran pada kolom yang sudah tersedia.

media

Pada penilaian aspek kualitas pembelajaran menggunakan angket yang berisi pertanyaan yang berhubungan dengan aspek rekayasa perangkat lunak, aspek komunikasi visual, aspek kesesuaian media dan materi pembelajaran dan aspek desain pembelajaran yang dilakukan oleh validasi ahli media dan ahli materi serta guru dan siswa yang hanya memberikan tanggapan terhadap virtual lab dimana penilaian dilakukan dengan menunjukkan virtual lab yang telah dibuat terlebih dahulu.

\section{Teknik Analisis Data.}

Analisis data hasil validasi tim ahli dilakukan dengan menggunakan 3 skor penilaian. Persentase hasil validasi dihitung dengan menggunakan persamaan sebagai berikut:

$$
X=\frac{\Sigma X}{N}
$$

Keterangan:

$X$ : Skor rata-rata penilaian oleh validator

$\Sigma X$ : Jumlah skor yang diperoleh validator

$N$ : Jumlah data

Data tentang instrumen penilaian kelayakan media pembelajaran virtual laboratory oleh ahli media dan ahli materi dengan memasukkan jawaban 
sesuai skornya dengan cara sebagai berikut

Rentang = data terbesar - data terkecil

$$
\begin{aligned}
& =3-1 \\
& =2
\end{aligned}
$$

Setelah memperoleh rentang, langkah selanjutnya adalah menentukan panjang interval kelas $(P)$ (Sudjana 2005).

$$
\begin{gathered}
P=\frac{\text { Rentang }}{\text { Kelas yang dihendak } i} \\
=\frac{2}{3}=0,67
\end{gathered}
$$

Berdasarkan hasil interval kelas di atas, maka kriteria kelayakan media pembelajaran virtual laboratory oleh ahli dapat dilihat pada Tabel 1.

Tabel 1. Kriteria penilaian oleh pakar

\begin{tabular}{ccc}
\hline No & Rentang Skor & Kriteria \\
\hline 1. & $2,33<$ atau $\leq$ & Sangat \\
& 3 & Baik \\
2. & $1,65<$ atau $\leq$ & Baik \\
& 2,32 & \\
3. & $0,92<$ atau $\leq$ & Kurang \\
& 1,64 & Baik \\
4. & $0,29<$ atau $\leq$ & Tidak Baik \\
& 0,91 & \\
\hline
\end{tabular}

b. Data tanggapan guru dan siswa terhadap virtual laboratory masing-masing dihitung dengan tabulasi data kemudian jawaban dimasukkan sesuai skornya. Perhitungan yang sama juga dilakukan pada angket tanggapan guru dan siswa, skor 4 untuk jawaban SS, skor 3 untuk jawaban $\mathrm{S}$, skor 2 untuk jawaban KS dan skor 1 untuk jawaban TS. Berikut ini disajikan kriteria nilai tanggapan guru dan siswa terhadap media pembelajaran

\begin{tabular}{|c|c|c|}
\hline No & $\begin{array}{l}\text { Rentang } \\
\text { Skor }\end{array}$ & Kriteria \\
\hline 1. & $\begin{array}{c}3,25<\text { atau } \\
\leq 4\end{array}$ & $\begin{array}{c}\text { Sangat } \\
\text { Mendukung }\end{array}$ \\
\hline 2. & $\begin{array}{c}2,50<\text { atau } \\
\leq 3,25\end{array}$ & \\
\hline 3. & $\begin{array}{c}1,75<\text { atau } \\
\leq 2,50\end{array}$ & $\begin{array}{r}\text { Kur } \\
\text { Mend }\end{array}$ \\
\hline 4. & $\begin{array}{c}1<\text { atau } \\
1,75\end{array}$ & $\begin{array}{c}\text { Tidak } \\
\text { Mendukung }\end{array}$ \\
\hline
\end{tabular}
virtual laboratory pada Tabel 2.

Tabel 2. Kriteria nilai tanggapan guru dan siswa

Dimodifikasi dari Yamasari 2010 Berdasarkan hasil kriteria yang diperoleh maka dihitung persentase tanggapan responden dengan rumus sebagai berikut.

$P=\frac{n}{N}=100 \%$

Keterangan:

$\mathrm{P}=$ angka persentase

$\mathrm{n}=$ skor riil

$\mathrm{N}=$ skor total

\section{HASIL DAN PEMBAHASAN}

\section{Perancangan LKPD}

Pembuatan virtual lab ini menggunakan program Power Point. Tahap pembuatan virtual lab ini berdasarkan storyboard yang telah dibuat. Adapun tahap pembuatan virtual lab yang dikembangkan dalam penelitian ini terdiri dari:

a. Bagian pendahuluan

Bagian awal virtual lab ini terdiri dari cover, login, petunjuk pemakaian dan daftar praktikum yang ingin dilakukan. 
Cover/tampilan awal virtual lab ini sebagai pembuka ketika program virtual lab mulai dijalankan. Cover/tampilan ini muncul bersamaan dengan halaman login. Halaman login pengguna ini berfungsi untuk dialihkan ke halaman daftar praktikum. Bentuk tampilan awal virtual lab dapat dilihat pada Gambar 1.

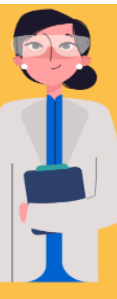

Gambar 1 virtual lab hasil pengembangan

Setelah pengguna mengklik tombol login, pengguna akan dialihkan ke halaman daftar praktikum untuk memilih praktikum yang ingin dilakukan. Tampilan halaman daftar praktikum dapat dilihat pada Gambar 2.

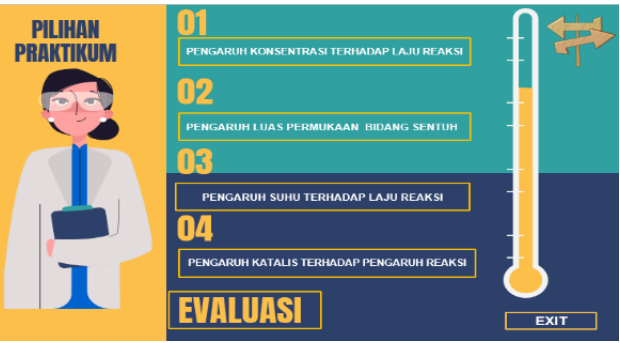

Gambar 2. Daftar praktikum virtual lab hasil pengembangan

b. Bagian isi

Bagian isi virtual lab terdapat empat macam tergantung praktikum apa yang ingin dilakukan oleh pengguna. Secara umum, bagian isi virtual lab dalam praktikum ke halaman daftar praktikum untuk memilih praktikum yang ingin dilakukan ini sama yaitu terdiri dari tujuan percobaan, alat dan bahan, prosedur kerja, dan pelaksanaan.

Tujuan percobaan akan muncul ketika pengguna sudah memilih praktikum yang ingin dilakukan dengan mengklik icon yang terdapat pada halaman daftar praktikum virtual lab hasil pengembangan. Fungsi dari tujuan praktikum yang terdapat dalam virtual lab adalah agar pengguna tahu apa yang akan dicapai dalam praktikum yang sedang dilakukan menggunakan virtual lab. Tampilan tujuan percobaan ke halaman daftar praktikum untuk memilih praktikum yang ingin dilakukan dapat dilihat pada gambar 4.

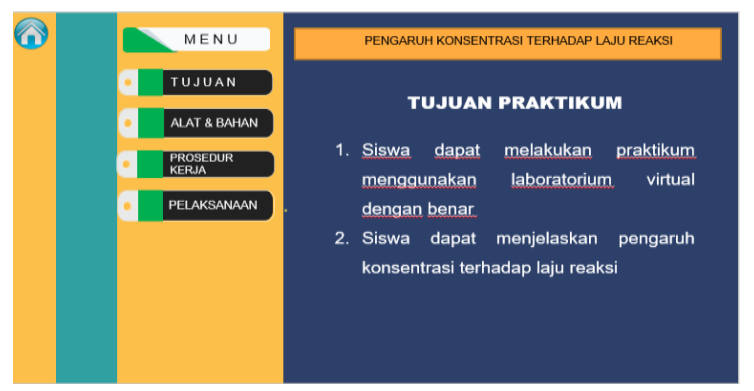

Gambar 3. Tampilan tujuan percobaan virtual lab hasil pengembangan

Setelah

pengguna mengetahui apa tujuan percobaan dari praktikum yang ingin dilakukan, pengguna akan dialihkan ke alat dan bahan dengan mengklik icon yang terdapat pada halaman pada tampilan tujuan percobaan yang akan dilakukan. Tampilan alat dan bahan dapat dilihat pada Gambar 4. 


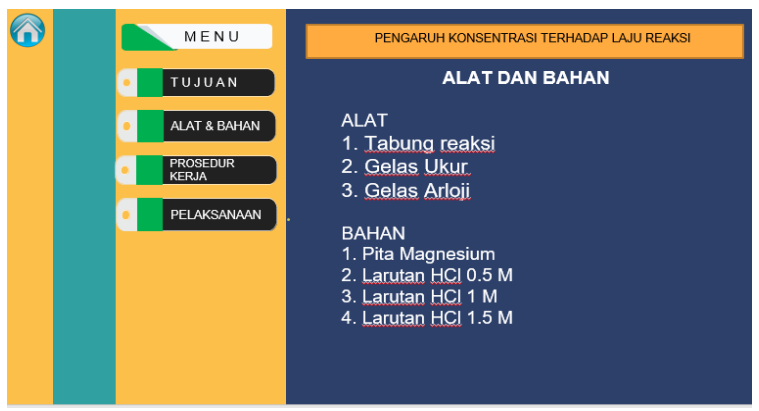

Gambar 4. Tampilan alat dan bahan virtual lab hasil pengembangan

Tampilan alat dan bahan laboratorium virtual lab hasil pengembangan. Sebelum pelaksanaan praktikum dilakukan siswa diharapkan untuk mengamati terlebih dahulu alat dan bahan yang ada. Contoh tampilan prosedur kerja praktikum pada virtual lab hasil pengembangan dapat dilihat pada Gambar 5.

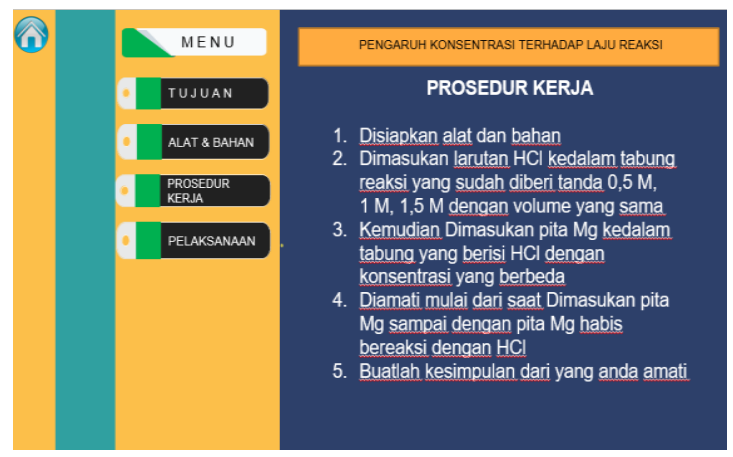

Gambar 6. Prosedur kerja praktikum pada virtual lab hasil pengembangan

Prosedur kerja laju reaksi akan ditampilkan jika pengguna mengklik halaman prosedur kerja. Siswa diharapkan dapat mengamati terlebih dahulu sebelum melangkah ke tahap selanjutnya yaitu pelaksanaan praktikum. Contoh tampilan pelaksanaan pada virtual lab hasil pengembangan dapat dilihat pada Gambar 7.

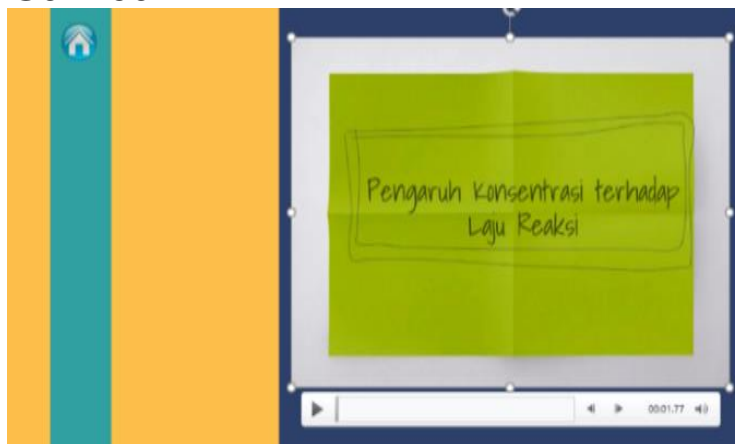

Gambar 7. tampilan praktikum pada virtual lab hasil pengembangan

Setelah

mengamati pelaksanaan praktikum laju reaksi, siswa diarahkan ke menu evaluasi. Setelah menggunakan virtual lab hasil pengembangan siswa melanjutkan ke halaman evaluasi untuk menjawab pertanyaanpertanyaan yang diberikan. Pertanyaan-pertanyaan ini bertujuan untuk membantu pemahaman siswa pada materi laju reaksi. Setelah semua pertanyaan selesai dijawab, klik menu selanjutnya pada pertanyaan terakhir untuk mengetahui nilai yang didapatkan. Tampilan pertanyaan-pertanyaan dalam praktikum laju reaksi pada virtual lab hasil pengembangan dapat dilihat pada Gambar 7.

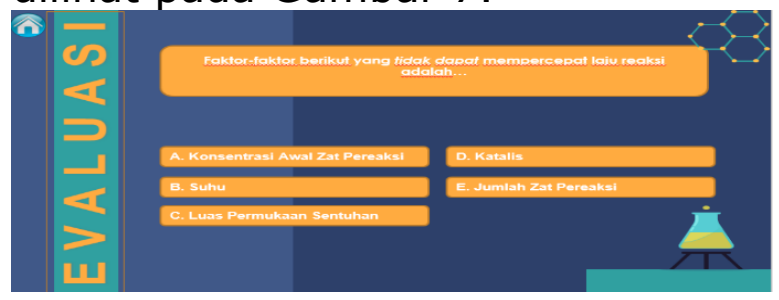

Gambar 7. Contoh tampilan soal dalam praktikum laju reaksi pada virtual lab hasil pengembangan 


\section{Tahap Pengembangan (Development)}

Produk yang dihasilkan divalidasi oleh 2 orang validator dimana dosen ahli media dan ahli materi. Validator melakukan validasi dengan mengisi lembar penilaian kelayakan media pembelajaran virtual lab. Peneliti melakukan validasi kepada validator untuk memperoleh kritikan dan saran dari validator. Tahap pengembangan (development) ini meliputi dua langkah, yaitu:

\section{Melaksanakan validasi}

Validasi virtual lab yang dilakukan dalam penelitian ini menggunakan lembar validasi yang bertujuan untuk mengetahui kelayakan produk yang dihasilkan. Penilaian virtual lab yang telah dikembangkan menghasilkan nilai presentase yang berbeda-beda dari tiap validator. Hasil penilaian produk virtual lab sebelum revisi yang dinilai oleh dua orang validator.

Berdasarkan hasil uji kelayakan produk virtual lab oleh validator ahli pada tahap I dengan penilaian pada aspek media yaitu diperoleh data bahwa media pembelajaran virtual lab yang dikembangkan pada materi faktorfaktor yang mempengaruhi laju reaksi mempunyai skor kelayakan 2,25 sehingga digolongkan ke dalam kriteria baik. Untuk hasil uji kelayakan produk media pembelajaran virtual lab oleh ahli materi yaitu diperoleh data bahwa virtual lab yang dikembangkan pada materi faktor-faktor yang mempengaruhi laju reaksi mempunyai skor kelayakan 2,41 sehingga digolongkan ke dalam kriteria sangat baik.

Setelah media pembelajaran virtual lab direvisi kembali oleh peneliti maka dilanjutkan pada validasi tahap II, validator melakukan validasi sama dengan tahap sebelumnya. Tahap ini dilakukan untuk membandingkan hasil validasi pertama dan kedua untuk kemudian melihat perbedaan setelah direvisi untuk menilai kelayakan media pembelajaran virtual lab. Peneliti melakukan kembali validasi kepada validator untuk memperoleh kritikan dan saran dari validator.

Berdasarkan hasil uji kelayakan produk media pembelajaran virtual lab oleh validator ahli pada tahap II dengan penilaian pada aspek media yaitu diperoleh data bahwa media pembelajaran virtual lab yang dikembangkan pada materi faktorfaktor yang mempengaruhi laju reaksi mempunyai skor kelayakan 2,91 sehingga digolongkan ke dalam kriteria sangat baik. Untuk hasil uji kelayakan produk media pembelajaran virtual lab oleh ahli materi yaitu diperoleh data bahwa media pembelajaran virtual lab yang dikembangkan pada materi faktor-faktor yang mempengaruhi laju reaksi mempunyai skor kelayakan 2,83 sehingga digolongkan ke dalam kriteria sangat baik. Hasil persentase pada tahap I dan II terlihat jelas perbandingan yaitu dari kategori baik menjadi sangat baik hal dilakukan perubahan berdasarkan 
komentar dan saran dari masingmasing validator. Hal ini didukung dari penelitian yang dilakukan oleh Felintina, 2011 yang menyatakan bahwa virtual lab sebagai media pembelajaran berbasis komputer layak digunakan, dimana penilaian pakar materi dengan kriteria sangat baik dan penilaian pakar media kriteria baik.

\section{Hasil Uji Coba Terbatas}

1) Hasil uji coba terbatas

Terhadap Guru

Peneliti melakukan uji coba terbatas. Uji coba terbatas dilaksanakan di SMA Negeri 02 Bombana, yang terdiri dari penyebaran angket tanggapan guru dan tanggapan siswa. Guru yang memberikan tanggapan pada virtual lab hasil pengembangan ini adalah 2 orang guru bidang studi kimia lulusan Pendidikan kimia yang sudah berpengalaman dalam mengajarkan pelajaran kimia. Pada tahap ini guru diminta untuk memberikan tanggapan terhadap virtual lab dalam laju reaksi. Ratarata persentase tanggapan guru terhadap media pembelajaran virtual lab sebesar $50 \%$ dengan Kriteria mendukung. Berikut adalah hasil penilaian guru terhadap virtual lab hasil pengembangan.

Tabel 3. Hasil Tanggapan Guru terhadap produk yang dikembangkan

\begin{tabular}{lllcc}
\hline No & \multicolumn{1}{c}{ Skor } & \multicolumn{1}{c}{ Kriteria } & $\begin{array}{c}\text { Jumlah } \\
\text { Responden }\end{array}$ & $\%$ \\
\hline 1 & $3,25<$ atau $\leq 4$ & Sangat Mendukung & 1 & $50 \%$ \\
2 & $2,50<$ atau $\leq 3,25$ & Mendukung & 1 & $50 \%$ \\
3 & $1,75<$ atau $\leq 2,50$ & Kurang Mendukung & 0 & 0 \\
& $1<$ atau $\leq 1,75$ & Tidak Mendukung & 0 & 0 \\
\hline
\end{tabular}

Pada tanggapan media pembelajaran virtual lab saran dari guru. Secara umum menurut guru, virtual lab yang telah direvisi sebelumnya berdasarkan saran validator ini sudah sesuai dan mudah digunakan.

\section{Hasil uji coba terbatas Terhadap Siswa}

Aspek yang dinilai Tanggapan oleh siswa juga dilakukan di SMA Negeri 02 Bombana kelas XII IPA yang berjumlah 10 siswa. Pada tahap ini siswa diminta untuk memberikan tanggapan terhadap virtual lab dalam praktikum faktor-faktor yang mempengaruhi laju reaksi. Rata-rata persentase tanggapan siswa pada aspek kemudahan penggunaan virtual lab sebesar $90 \%$ dengan kriteria sangat mendukung dan $10 \%$ dengan kriteria mendukung. 
Tabel 4. Tanggapan siswa dari hasil uji coba terbatas

\begin{tabular}{|c|c|c|c|c|}
\hline No & Skor & Kriteria & $\begin{array}{c}\text { Jumlah } \\
\text { Responden }\end{array}$ & $\%$ \\
\hline 1 & $3,25<$ atau $\leq 4$ & $\begin{array}{l}\text { Sangat } \\
\text { Mendukung }\end{array}$ & 9 & $90 \%$ \\
\hline 2 & $2,50<$ atau $\leq 3,25$ & Mendukung & 1 & $10 \%$ \\
\hline
\end{tabular}

Berdasarkan Tabel siswa memberi tanggapan "sangat mendukung" dan "mendukung" terhadap virtual laboratory. Jumlah responden dengan tanggapan "sangat mendukung" lebih besar dibanding responden dengan tanggapan "mendukung". Berdasarkan tanggapan siswa tersebut dapat disimpulkan bahwa virtual laboratory diterima dengan baik karena mencapai skor $\geq 2,51$. Selanjutnya, untuk mengetahui rerata skor butir tanggapan siswa dapat dilihat pada Tabel 5.

Tabel 5. Tanggapan siswa pada uji coba skala terbatas

\begin{tabular}{|c|c|c|c|}
\hline No & Tanggapan & $\begin{array}{c}\text { Skor } \\
\text { rata-rata }\end{array}$ & Kriteria \\
\hline 1 & Ketertarikan menggunakan media & 3,8 & $\begin{array}{l}\text { Sangat } \\
\text { mendukung }\end{array}$ \\
\hline 2 & $\begin{array}{l}\text { Media susuai dengan tujuan } \\
\text { pembelajaran }\end{array}$ & 3,4 & $\begin{array}{l}\text { Sangat } \\
\text { mendukung }\end{array}$ \\
\hline 3 & Media mudah dipoerasikan & 3,6 & $\begin{array}{l}\text { Sangat } \\
\text { mendukung }\end{array}$ \\
\hline 4 & Media membantu pemahaman materi & 3,8 & $\begin{array}{l}\text { Sangat } \\
\text { mendukung }\end{array}$ \\
\hline 5 & Tampilan media menarik & 3,7 & $\begin{array}{l}\text { Sangat } \\
\text { mendukung }\end{array}$ \\
\hline 6 & $\begin{array}{l}\text { Media disertai Latihan soal dan } \\
\text { informasi baru }\end{array}$ & 3,6 & $\begin{array}{l}\text { Sangat } \\
\text { mendukung }\end{array}$ \\
\hline 7 & Media meningkatan motivasi belajar & 3,6 & $\begin{array}{l}\text { Sangat } \\
\text { mendukung }\end{array}$ \\
\hline 8 & Mednia digunakan secara mandiri & 3,3 & $\begin{array}{l}\text { Sangat } \\
\text { mendukung }\end{array}$ \\
\hline 9 & Media lebih efektif dan efisien & 3,2 & mendukung \\
\hline \multirow[t]{2}{*}{10} & $\begin{array}{l}\text { Ketwrtarikan menggunakan media pada } \\
\text { materi lain }\end{array}$ & 3,4 & $\begin{array}{l}\text { Sangat } \\
\text { mendukung }\end{array}$ \\
\hline & Rata-rata & 3,54 & $\begin{array}{l}\text { Sangat } \\
\text { mendukung }\end{array}$ \\
\hline
\end{tabular}


Rerata skor tiap butir tanggapan siswa sebagian besar menunjukkan tanggapan "sangat mendukung". Namun pada butir tanggapan no. 9 menunjukkan tanggapan mendukung. Dari kesepuluh butir tanggapan siswa, keberterimaan virtual laboratory sebagai media pembelajaran virtual lab mendapat kriteria "sangat mendukung" karena total rata-rata skor 3,54 telah mencapai indikator keberterimaan (skor $\geq$ 2,51).

Berdasarkan hasil angket, beberapa siswa memberi masukan dan kritik yang selanjutnya menjadi bahan pertimbangan untuk melakukan revisi produk. Masukan dan kritik dari siswa adalah tampilan background yang kurang bervariasi dan jumlah soal evaluasi sebanyak 10 buah dianggap kurang banyak. Ada sebagian kecil siswa yang merasa belum puas atas informasi yang telah disampaikan, walaupun penyampaian informasi yang ada dalam virtual laboratory cukup mudah dipahami. Pada hasil uji coba terbatas yang dilakukan oleh guru dan siswa pada virtual lab hasil pengembangan memiliki kategori sangat mendukung. Kategori sangat mendukung juga didapatkan dari hasil tanggapan siswa terhadap media pembelajaran virtual lab yang dikembangkan sehingga dapat disimpulkan bahwa virtual lab hasil pengembangan layak digunakan.

\section{KESIMPULAN}

Berdasarkan hasil penelitian dan pembahasan dapat diambil kesimpulan sebagai berikut:

1. Virtual lab dalam praktikum faktor-faktor yang mempengaruhi laju reaksi yang dikembangkan dinyatakan valid dan layak digunakan dalam pembelajaran di sekolah.

2. Hasil tanggapan guru serta tanggapan siswa terhadap media pembelajaran virtual lab memiliki kategori sangat mendukung.

\section{DAFTAR PUSTAKA}

Carnevale, D. 2003. The Virtual Lab Experiment. The Chronicle of Higher Education. 1(1): 1-5.

Chan, C. 2009. Evaluating learning experiences in virtual laboratory training through student perceptions: a case study in Electrical and Electronic Engineering at the University of Hong Kong. Journal of the Higher Education Academy Engineering Subject Centre 4, (2): 10. On Line at www.engin education.html.

Felintia, Y. 2011. Pengembangan Virtual Laboratory Sebagai Media Pembelajaran Berbasis Komputer pada Materi Pembiakan Virus. Skripsi. Universitas Negeri Semarang. 
Hamida, N., Bakti, M., dan Budi, U. 2013. Studi Komparasi Penggunaan laboratorium Virtual Dan Laboratorium Riil Dalam Pembelajaran Student Teams Achievment Division Terhadap Prestasi Belajar Ditinjau Dari Kreativitas Siswa Pada Materi Pokok Sistem Koloid Kelas XI Semester Genap SMA Negeri 1 Banyudono Tahun Pelajaran 2011/2012. Jurnal Pendidikan Kimia. 2(2): 7-15.

Khaeruman., Yusran, K., dan Murdiono. 2015. Pengembangan Laboratorium Virtual pada materi Lartuan Elektrolit dan Non-Elektrolit. Jurnal IImiah IKIP Mataram. 3(2): 2355-6358.

Susanti. 2014. Pengembangan Model Laboratorium Virtual sebagai Solusi Keterbatasan Sumber Daya Pembelajaran. Prosiding Seminar Nasional Aplikasi Sains \& Teknologi (SNAST). ST AKPRIND Yogyakarta. 301-306.

Mustikasari A. 2008. Mengenal Media Pembelajaran. On Line at http://edu-articles.com.

Nuh, M. 2014. Permen Nomor 59 tentang Kurikulum SMA, Karakteristik Mata Pelajaran Kimia Lampiran III 10d tentang Mapel Peminatan Kimia. Kementrian Pendidikan dan Kebudayaan RI. Jakarta.
Nurrokhmah, I.E., dan W. Sunarto. 2013. Pengaruh Virtual Lab Berbasis Inkuiri terhadap Hasil Belajar Kimia. Jurnal Pendidikan Kimia. 2(1): 200207.

Pujiati, A. dan Nurhayati. 2012. Pengaruh Model Pembelajaran (Berbantuan Laboratorium Virtual) dan Minat Belajar Tehadap Kemampuan Berpikir Kreatif Kimia. Jurnal Universitas Indraprasta PGRI. Jakarta.

Rahayu, S. U., Fuldiaratman., dan Ernawati. 2014. Pengaruh Media Laboratorium Virtual dalam Pembelajaran Larutan Penyangga Terhadap Hasil Belajar Siswa Kelas XI IPA SMAN 8 Muaro Jambi. Skripsi tidak diterbitkan. Jambi: Universitas Jambi.

Sadiman, A., Rahardjo., Haryono., dan Rahardjito. 2006. Media Pendidikan, Pengertian, Pengembangan dan Pemanfaatannya. Jakarta: PT Raja Grafindo Persada.

Saguni F. 2006. Prinsip-prinsip kognitif pembelajaran multimedia: pesan modality dan contiguity terhadap peningkatan hasil belajar. $\begin{array}{lll}\text { INSAN } & 8 & (3): 130\end{array}$ http://journal.unair.ac.id.

Saleh KF, Mohamed AM \& Madkour H. 2009. Developing virtual laboratory environment for 
engine education. International Journal of Arts and Sciences 3(1):9-17.
Pembelajaran. On Line at http://romisatriawahono.net.

Soehendro, B. 2006. Panduan Penyusunan Kurikulum Tingkat Satuan Pendidikan Jenjang Pendidikan Dasar Dan Menengah. Badan Standar nasional Pendidikan. Jakarta.

Sudjino dan Waldjinah. 2009. Pembelajaran IPA Terpadu untuk Kelas VII SMP/MTS. Jakarta: PT. Intan Pariwara.

Sudrajat, A. 2008. Media Pembelajaran. On Line at http://akhmadsudrajat.wordp ress.com .

Sunendar, T. 2007. Pemanfaatan Laboratorium Kimia Virtual. On Line at www.Ipmpjabar.go.id.

Suyatna. 2009. Efektifitas Penggunaan Software Platetec pada Pembelajaran Dinamika Bumi. On Line at http://pustakailmiah.unila.ac. id.

Tim Puslitjaknov. 2008. Metode Penelitian Pengembangan. Jakarta: Pusat Penelitian Kebijakan dan Inovasi Pendidikan Badan Penelitian dan Pengembangan Departemen Pendidikan Nasional.

Wahono, R. S. 2006. Aspek dan Kriteria Penilaian Media 